\title{
Analysis Level of Satisfaction Student P3d for Distance Learned Based End-User Computing Satisfaction (Eucs) Method in the COVID-19 Era
}

\author{
Anita Merry Cisca ${ }^{1}$, Sri Wahyuni Nasution ${ }^{2}$, Sri Lestari Ramadhani Nasution ${ }^{3}$, Ermi \\ Girsang ${ }^{4}$ \\ ${ }^{1,2,4}$ Program Study Magister Public Health, Faculty of Medical, Universitas Prima Indonesia, Medan, North \\ Sumatera, Indonesia \\ ${ }^{3}$ Department of Tropical Medicine, Faculty of Medicine, University of Prima Indonesia, Medan, Indonesia \\ ermigirsang@unprimdn.ac.id
}

\begin{abstract}
This work aims to investigate an Indonesian EFL student's perceptions and experiences in repeatedly doing standardized English language proficiency test: TOEIC (Test of English for International Communication) and TOEFL (Test of English as a Foreign Language). This standardized test has a significant role in the academic and professional lives of students (Anam, 2019); it contributes positively to students' language proficiency and their future employment if they have higer and valid score in the test (Hsieh, 2017). This present study interviewed an Indonesian EFL student at a National University in Taiwan running an international program. The study participant passed the exam, but she did it repeatedly before she could pass it. This study used a qualitative phenomenological approach with an in-depth interview. The relevant findings illustrate that the participant reveals the reasons for failing the test: lack of self-awareness, lack of selfconfidence, and the distance of the test venue from her dormitory. On the contrary, she passed the test by doing online simulation exam individually and modifying her study skills while preparing for the test. The failure process had a positive impact on her in making her to know her ability.
\end{abstract}

Keywords satisfaction; P3D students, ECS method, distance learning

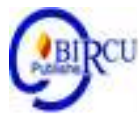

\section{Introduction}

The Minister of Education also issued Circular Number 4 of 2020 concerning the Implementation of Education Policies in an Emergency for the Spread of Coronavirus Disease (Covid-19) that the learning process from home is carried out with several provisions such as through online / distance learning which is carried out to provide a meaningful learning experience for students, without being burdened with demands to complete all curriculum achievements for class and graduation, learning from home can also be focused on life skills education, including regarding the Covid-19 pandemic, as well as learning activities and tasks from home can vary between students, according to their interests and conditions -Each includes considering gaps in access/learning facilities at home, evidence or products of learning activities from home are given qualitative and useful feedback from the teacher, without being required to provide a quantitative score/value (Kemendikbud RI, 2020).

The Covid-19 Pandemic situation has had an impact on various sectors including P3D which resulted in the imposition of distance learning at several universities in Indonesia. In obtaining and achieving these clinical skills, P3D students need to interact 
directly with patients and other medical personnel in the teaching hospital environment while still paying attention to the applicable Covid-19 health protocol.

The increased case of COVID-19 has affected the world economy including Indonesia. The COVID-19 pandemic that has been established by the UN, affects the transportation, tourism, trade, health and other sectors. The "lock down" policy is taken by various countries to prevent further spread of covid-19, so that economic activities are hindered and put pressure on the world's economic growth in the future including Indonesia's economic growth (Susilawati, 2020). The current COVID-19 lockdown situation has had an impact on people's connectedness by limiting their allowed behaviours, resulting in a negative impact on people's mental health and well-being on the whole (Oe, 2020). The enhancement of human interaction and networking to sustain people's mental health has been on the emergent agenda during the current COVID-19 situation (Oe, 2020).

Covid-19 is very influential in achieving competency standards. The limitation of physical activity alone only allows the fulfillment of the cognitive aspects online. The psychomotor and affective aspects themselves cannot be replaced with online distance education models, especially in the psychomotor aspects. Meanwhile, clinical skills at the professional level are mandatory. If a prospective doctor does not receive sufficient case exposure and minimum skills, competency attainment will be difficult.

Prima Indonesia P3D students who have also experienced the impact of the Covid-19 era are the same as other universities, namely conducting online distance education programs, where students can only interact with supervisors in discussing cases online, students cannot perform clinical skills directly to patients and discussing with supervisors at the P3D Teaching Hospital in RSU. Royal Prima Medan.

In the distance learning system at RSU. Royal Prima enforces the division of the study load into two types of learning systems, namely $75 \%$ of each department's learning is carried out by a distance learning system and $25 \%$ is carried out face-to-face by participating in direct activities at the RSU. Royal Prima Medan, all learning system activities are arranged with a rotation system. Thus resulting in changes in the amount of study load in each department by distance learning and direct activities at the hospital. Royal Prima Medan

Based on the research background, a research problem can be formulated, namely how the level of satisfaction of P3D students towards distance learning in the Covid-19 pandemic era by using the End-User Computing Satisfaction (EUCS) method at RSU. Royal Prima Medan. To analyze the level of satisfaction of P3D students with distance learning in the Covid-19 pandemic era using the End-User Computing Satisfaction (EUCS) method at RSU. Royal Prima Medan.

\section{Research Methods}

This research is a type of quantitative analytical research with an explanatory research design in the form of a survey method and using a cross-sectional approach, namely by collecting data at once to describe student distance learning in the medical education professional program organized by RSU. Royal Prima Medan as an effort to suppress the chain of the spread of Covid-19.

The variables in this study are independent, namely the content dimension, the accuracy dimension, the format dimension, the ease of use dimension, the timeliness dimension measured by the End-Method. User Computing Satisfaction (EUCS) and the dependent variable, namely the level of satisfaction of P3D students. 
Primary data is obtained directly from respondents in the study. Data collection was carried out by using a multiple-choice questionnaire method which was outlined in the form of a Google Form. Secondary data were obtained by researchers from Komkordik RSU. Royal Prima Medan regarding the total number of P3D students for the 2020-2021 academic year with 76 students. While the research sample is using a total sample of 76 respondents.

\section{Results and Discussion}

\subsection{Results}

Independent and dependent variable data were collected through a questionnaire distributed in the form of google form by accessing the URL address given to all respondents. The questionnaire consists of 5 point dimensions with each point totaling 4 question items. To find out the categories of answers to the questionnaire submitted are included in the categories Strongly Agree (SS), Agree (S), Disagree (TS), Strongly Disagree (STS). Then an analysis was carried out using the Likert method. As for the steps to determine the level of achievement of respondents in each dimension, the following formula is used (Saputra, 2019): Achievement Level $=($ Average Score $) /($ Maximum Ideal Score) $\mathrm{x} 100 \%$

From the calculation steps above, the category range is obtained, the category range of each dimension based on the average score of the maximum total of each dimension is categorized back into the category as satisfied with a score $>75 \%$, less satisfied $40 \%$ $74.9 \%$, and Not satisfied $<40 \%$ are as follows:

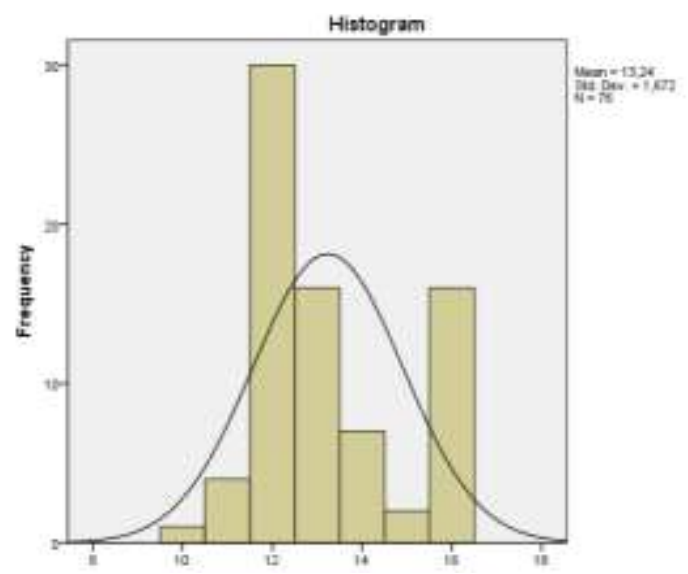

Figure 1. Variable Content

Achievement Level $=13.24 / 16$ X 100\% $=82.75 \%$

From the calculation results on the content dimension variable above, it shows the value (>75\%), namely $82.75 \%$, which means that the respondent is satisfied with the content dimension given in distance learning. 


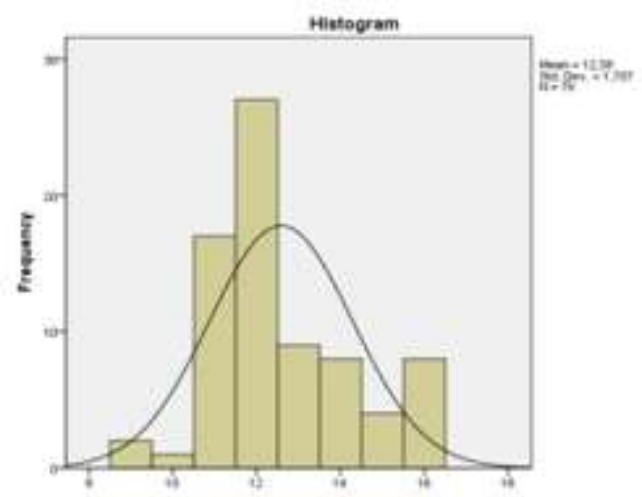

Figures 2. Variables Accuracy

Achievement Level $=12.58 / 16$ X 100\% $=78.62 \%$

From the calculation results on the Accuracy dimension variable above, the value (> $75 \%$ ) is $78.62 \%$, which means that the respondent is satisfied with the Accuracy dimension given to distance learning.

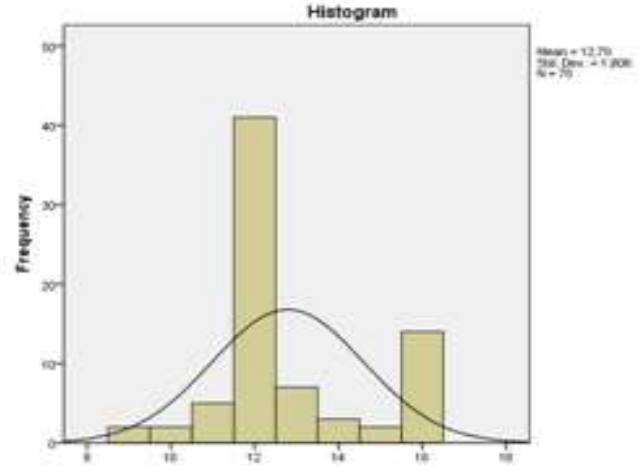

Figures 3. Variables Format

Achievement Level $=12.79 / 16 \times 100 \%=79.93 \%$

From the calculation results on the Format dimension variable (Shape) above, it shows the value (> 75\%) 79.93\%, which means that the respondent is satisfied with the format dimension given to distance learning.

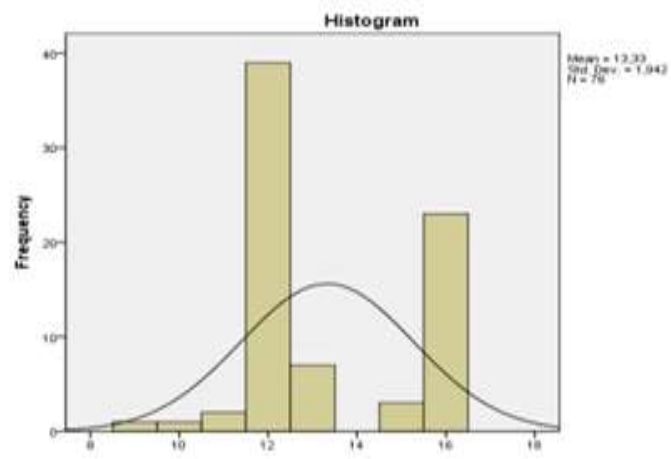

Figures 4. Variables Ease Of us

Achievement Level $=13.33 / 16$ X 100\% $=83.31 \%$ 
From the calculation results on the Ease of Use dimension variable above, the value (>75\%) is $83.31 \%$, which means that the respondent is satisfied with the Ease of Use dimension given to distance learning.

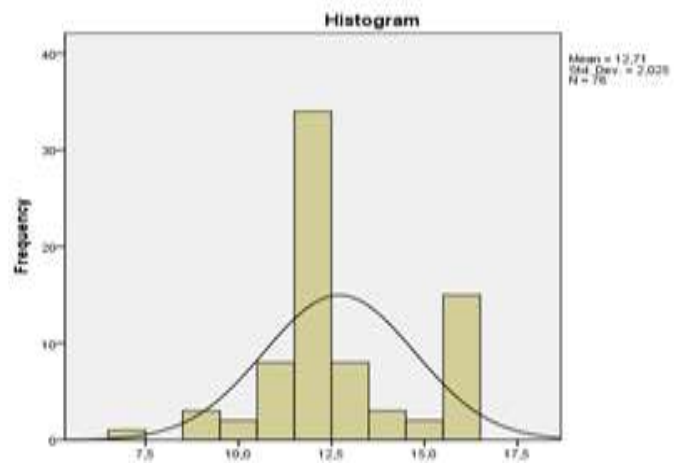

Figures 5. Variables Time lines

Achievement Level $=12.71 / 16$ X 100\% $=79.43 \%$

From the calculation results on the dimension of Timeliness above, the value (> $75 \%$ ) is $79.43 \%$, which means that the respondent is satisfied with the Timelines dimension given to distance learning.

\subsection{Pearson Product Moment Correlation Test}

Bivariate analysis in this study was used to legally analyze the correlation of the independent variables, namely the dimensions of content, accuracy, format, ease of use, and timeliness with the dependent variable, namely user satisfaction. ) and see the percentage of each variable. Then proceed with the Pearson correlation test at the $95 \%$ confidence level. It can be seen that table 4:13 shows that all independent variables, namely the dimensions of content, accuracy, format, ease of use, and timeliness have a significant correlation with the dependent variable, namely satisfaction (User satisfaction). ) which can be seen from the probability value below $0.05(\mathrm{p}<0.005)$.

Table 1. Correlation Test Results of Independent Variables with Dependent Variables

\begin{tabular}{lcccc}
\hline $\begin{array}{c}\text { Test Results Pearson } \\
\text { Correlation }\end{array}$ & $\begin{array}{c}\text { Correlation } \\
\text { Coefficient (r) }\end{array}$ & $\begin{array}{c}\text { Regression Coefficient } \\
\text { (Beta) }\end{array}$ & Significance Value (p) & $\mathbf{R}_{\text {square }}$ \\
\hline Content & 0,671 & $-0,035$ & 0,000 & 0,689 \\
Accuracy & 0,670 & $-0,012$ & 0,000 & 0,000 \\
Format (Shape) & 0,766 & 0,438 & 0,000 & \\
Ease (Ease Of Use) & 0,741 & 0,350 & 0,000 & \\
Timeliness & 0,736 & 0,170 & & \\
\hline
\end{tabular}

Based on table above, we can see the percentage of influence of the independent variable from each dimension on the dependent variable, using the following formula:

SE (X)\% = Betax X Correlation Coefficient X 100\% and SR (X)\% $=(\mathrm{SE}(\mathrm{X}) \%) / \mathrm{R} \_$square a. Percentage of the Influence of Content Dimensions on the Satisfaction Level of P3D Students

SE $(\mathrm{X} 1) \%=-0.035 \times 0.671 \times 100 \%=-2.35 \%$

$\mathrm{SR}(\mathrm{X} 1) \%=(-2,35) / 68,9=-3,41 \%$

Based on the formula above, it is known that the percentage of influence of the content dimension on the satisfaction level of P3D students is $-3.41 \%$. 
b.Percentage of the Influence of the Dimension of Accuracy on the Satisfaction Level of P3D Students

SE $(X 1) \%=-0,012 \times 0.670 \times 100 \%=-0.80 \%$

$\mathrm{SR}(\mathrm{X} 1) \%=(-0,80) / 68,9=-1,16 \%$

Based on the formula above, it is known that the percentage of influence of the content dimension on the satisfaction level of P3D students is $-1.16 \%$.

c. Percentage of the Influence of Format Dimensions (Forms) on the Satisfaction Level of P3D Students

SE $(\mathrm{X} 1) \%=-0,438 \times 0.671 \times 100 \%=33.55 \%$

SR $(X 1) \%=33.55 / 68.9=48.69 \%$

Based on the formula above, it is known that the percentage of the influence of the content dimension on the satisfaction level of P3D students is $48.69 \%$.

d. Percentage of Effect of Ease of Use Dimensions on Satisfaction Levels of P3D Students $\mathrm{SE}(\mathrm{X} 1) \%=0.350 \times 0.741 \times 100 \%=25.93 \%$

$\mathrm{SR}(\mathrm{X} 1) \%=25.93 / 68.9=37.63 \%$

Based on the formula above, it is known that the percentage of the influence of the content dimension on the satisfaction level of P3D Students is $37.63 \%$.

e. Percentage of the Influence of Content Dimensions on the Satisfaction Level of P3D Students

SE $(X 1) \%=0.170 \times 0.736 \times 100 \%=12.51 \%$

$\mathrm{SR}(\mathrm{X} 1) \%=12.51 / 68.9=18.15 \%$

Based on the formula above, it is known that the percentage of the influence of the content dimension on the satisfaction level of P3D students is $18.15 \%$.

The $\mathrm{F}$ test is used to determine the overall effect between the independent variables, namely the dimensions of Content, Accuracy, Format, Ease of Use, and Timeliness on the dependent variable, namely User satisfaction. If the sig value $<0.05$ or $\mathrm{F}$ count is greater than the $\mathrm{F}$ table then there is a simultaneous influence on the dependent variable, and if the sig value $>0.05$, or $\mathrm{F}$ count is less than the $\mathrm{F}$ table then there is no simultaneous influence on the dependent variable.

Tables 2. Test Results of the Effect of Independent Variables on Dependent Variables

\begin{tabular}{ccccccc}
\hline & Model & Sum of Squares & df & Mean Square & F & Sig. \\
\hline \multirow{2}{*}{1} & Regression & 245,304 & 5 & 49,061 & 30,954 &, 000 \\
& Residual & 110,946 & 70 & 1,585 & & \\
& Total & 356,250 & 75 & & & \\
\hline
\end{tabular}

Based on tables 2, it is known that the significance value of the effect of the independent variable simultaneously on the dependent variable is 0,000 smaller than the alpha value of 0.05 and the calculated $\mathrm{F}$ is 30,954 greater. ), Accuracy, Format, Ease of Use and Timeliness simultaneously on the dependent variable, namely User satisfaction. By looking at the $\mathrm{R}$ square value of 0.689 , it means that the independent variables simultaneously influence the dependent variable of 0.689 or $68.9 \%$. 


\section{Conclusion}

Based on the results of the research and discussion above, it can be concluded that:

1. There is an effect of the content dimension on User satisfaction with a significance value of 0.000 and a percentage of $-3.41 \%$ and indicates the Satisfied category $(>75 \%)$ with a percentage of results of $82.75 \%$.

2. The influence of the dimension of accuracy (Accuracy) on satisfaction (User satisfaction) with a significance value of 0.000 and a percentage of $-1.16 \%$ and indicates the category of Satisfied (> 75\%) with a result percentage of $78.62 \%$.

3. The influence of the Format dimension on User satisfaction with a significance value of 0,000 and a percentage of $48.69 \%$ and indicates the Satisfied category (> 75\%) with a result percentage of $79.92 \%$.

4. The influence of the dimension of ease (Ease of use) on satisfaction (User satisfaction) with a significance value of 0.000 and a percentage of $37.63 \%$ and indicates the category of Satisfied (> 75\%) with the percentage of results of $83.31 \%$.

5. The influence of the dimension of timeliness (Timeliness) on satisfaction (User satisfaction) with a significance value of 0.000 and a percentage of $18.5 \%$ and indicates the category of Satisfied (> 75\%) with a presentation of results of $79.43 \%$.

6. Independent variables, namely the dimensions of Content, Accuracy, Format, Ease of Use, and Timeliness, simultaneously influence the dependent variable, namely User satisfaction of $68.9 \%$.

\section{References}

Arikunto, S., 2012. Posedur Penelitian Suatu Pendekatan Praktek. Jakarta: Rineka Cipta.

Bušelić, M., 2012. Distance Learning - concepts and contributions. Prethodno priopćenje, 23-34.

Dalimunthe, N., \& Ismiati, C., 2016. Analisis Tingkat Kepuasan Pengguna Online Public Access Catalog (OPAC) Dengan Metode EUCS. Jurnal Rekayasa dan Manajemen Sistem Informasi 2 (1) 71-74.

Farajollahi, M., Zare, H., Hormozi, M., Sarmadi, M. R. \& Zarifsanaee., 2010. A conceptual model for effective distance learning in higher education. Turkish Online Journal of Distance Education. 11 (3), 63-77.

Firman, F., \& Rahayu, S., 2020.Pembelajaran Online di Tengah Pandemi Covid19.Indonesian Journal of Educational Science (IJES), 2(2), 81-89.

Fitriansyah, A., Harris, I., 2018. Pengukuran Kepuasan Pengguna Situs Web Dengan Metode End User Computing Satisfaction (EUCS). Jurnal Sistem Informasi 2 (1) 18.

Kemdikbud RI., 2020. Edaran Tentang Pencegahan Wabah COVID-19 di Lingkungan Satuan Pendidikan Seluruh Indonesia.

Kemendikbud R.I 2020. Edaran Tentang Pelaksanaan Pendidikan Dalam Masa Darurat Covid-19.

KEMENKES RI, P. P., 2020. Pedoman Pencegahan Dan Pengendalian Coronavirus Disease (Covid-19), Jakarta, Kementerian Kesehatan RI Direktorat Jendral Pencegahan dan Pengendalian Penyakit (P2P) Rev-3.

Konsil Kedokteran Indonesia., 2012. Standar Pendidikan Profesi Dokter Indonesia. Jakarta: Konsil Kedokteran Indonesia.

Maudiarti, S., 2018. Penerapan E-Learning di Perguruan Tinggi, 32 (1), 53-68. 
Moenir, H.A.S., 2016. Manajemen Pelayanan Umum di Indonesia. Jakarta: Bumi Aksara. Napitupulu, R.M., 2020. Dampak Pandemi Covid-19 Terhadap Kepuasan Pembelajaran Jarak Jauh, Jurnal Inovasi Teknologi Pendidikan I7 (1) 23-33.

Notoadmodjo, S., 2010. Metode Ilmu Pengetahuan. Dalam: Metologi Penelitian Kesehatan. Jakarta: Rineka Cipta, 1-127.

Oe, H., and Weeks, M. (2020). How to Support Vulnerable Citizens during the COVID-19 Lockdown: A Community Initiative from Ubiquitous Network Perspectives. Budapest International Research and Critics Institute-Journal (BIRCI-Journal). P. 1369-1377.

Panen,P.,dkk., 2016. Buku Panduan Penyelenggaraaan Model Pembelajaran Pendidikan Jarak Jauh di Perguruan Tinggi.Jakarta: Ristekdikti.

Pawirosumarto, S., 2016. Pengaruh Kualitas Sistem, Kualitas Informasi, dan Kualitas Layanan Terhadap Kepuasan Pengguna Sistem e-learning. Jurnal Ilmiah Manajemen, VI (3) 416-433.

Prasetya,T.A., \& Harjanto, T.C., 2020 Pengaruh Mutu Pembelajaran Online dan Tingkat Kepuasan Mahasiswa Terhadap Hasil Belajar Saat Pandemi Covid-19. Jurnal Pendidikan Teknologi dan Kejuruan,17 (2),188-197.

Pratiwi, E.W., 2020. Dampak Covid-19 Terhadap Kegiatan Pembelajaran Online Di Sebuah Perguruan Tinggi Kristen Di Indonesia. Perspektif Ilmu Pendidikan 34 (1) 18.

Restanti, A. S., \& Astuti, E.Y., 2017. Analisis End-User Computing Satisfaction pada Online Public Access catalogue "Izylib" di Lingkungan Universitas Jendral Soedirman. Jurnal of Library and Information Science 1 (1) 223-236.

Sailah, I.,2011. Panduan Penyelenggaraan Model Pembelajaran Pendidikan Jarak Jauh di Pergururan Tinggi. Jakarta : Kementerian Pendidikan Nasional, Direktorat Jendral Pendidikan Tinggi, Direktorat Pembelajaran dan Kemahasiswaan.

Saputra, A., \& kurniadi, D., 2019. Analisis Kepuasan Pengguna Sistem Informasi ECampus di IAIN Bukittinggi menggunakan Metode EUCS. Jurnal Vokasional Teknik Elektronika dan Informatika 7 (3) 58-66.

Saputri, N. A. O., \& Alvin., 2020. Pengukuran Tingkat Kepuasan Pengguna Pada Portal Program Studi Sistem Informasi Bina Darma Menggunakan Metode End User Computing Satisfaction. Jurnal of Information System and Informatics 2 (1) 154162.

Setyonigrum, N. R., 2020. Analisis Tingkat Kepuasan Pengguna Sistem Informatika Kerja Praktek dan Skripsi (SKKP) Menggunakan Metode End User Cmputing Satisfaction (EUCS). Jurnal of Applied Informatics and Computing (JAIC) 4 (1) 17-21.

Sulata, A.,\& Hakim, A.A., 2020.Gambaran Perkuliahan Daring Mahasiswa Ilmu Keolahragaan Unesa di Masa Pandemi Covid-19.Jurnal Kesehatan Olahraga $8(03), 147-156$.

Susilawati, et al. (2020). Impact of COVID-19's Pandemic on the Economy of Indonesia. Budapest International Research and Critics Institute-Journal (BIRCI-Journal). P. 1147-1156.

Taufik, A., 2019. Perspektif Tentang Perkembangan Sistem Pembelajaran Jarak Jauh Di Kabupaten Kutai Kartanegara Kalimantan Timur. Jurnal pendidikan: Riset dan Konseptual, 3 (2), 2598-5175.

WHO., 2020. Coronavirus disease (COVID-19, April 28) advice for the public.

Retrieved April 29, 2020, from https://www.who.int/emergencies/diseases/novelcoronavirus2019/advice-for-public. 
WHO., 2020. WHO Director-General's remarks at the media briefing on 2019 - n Covon 11 February 2020. Cited Feb 13 rd 2020. Available on: https://www.who.int/dg/speeches/detail/who-director-generals-remarks-at-the-mediabriefing-on-2019-ncov-on-11-february-2020.(Feb12th2020). 